\title{
ANALISIS KEMAMPUAN REPRESENTASI MATEMATIS MAHASISWA
}

\author{
Yumi Sarassanti \\ Pendidikan Matematika, STKIP Melawi \\ Jalan RSUD Melawi KM. 04, Nanga Pinoh, Melawi, Kalimantan Barat \\ e-mail: yumisarassanti@yahoo.co.id
}

\begin{tabular}{cccc}
\hline Submitted & Accepted & Published \\
$2021-01-03$ & $2021-04-26$ & $2021-04-30$ & OPEN \\
\hline
\end{tabular}

Abstrak

Tujuan penelitian untuk mengetahui bagaimana kemampuan representasi matematis mahasiswa STKIP Melawi. Metode penelitian yaitu kualitatif deskriptif dengan bentuk penelitian survei. Subjek penelitian berjumlah 25 orang dari populasi mahasiswa Pendidikan Matematika yaitu 51 orang. Subjek dipilih secara simple random sampling tanpa mengetahui kemampuan awal matematika setiap mahasiswa. Teknik pengumpulan data menggunakan teknik tes dan wawancara. Instrumen penelitian yang digunakan yaitu lembar soal tes kemampuan representasi dan pedoman wawancara. Analisis data yang digunakan yaitu reduksi data, penyajian data, dan penarikan kesimpulan. Mahasiswa diwawancarai setelah selesai menjawab soal-soal yang diberikan. Penyajian hasil olah data dalam bentuk deskripsi yang kemudian ditarik kesimpulan. Hasil penelitian menunjukkan bahwa mahasiswa yang menjawab soal sesuai indikator menggunakan representasi visual (gambar) untuk menyelesaikan masalah matematika dikategorikan tinggi dan mahasiswa yang menjawab soal sesuai dengan indikator melakukan translasi dari representasi verbal (tulisan) ke dalam representasi visual (gambar) matematika dengan tulisan dikategorikan rendah.

Kata Kunci: kemampuan; representasi matematis; bangun datar.

\begin{abstract}
The research objective was to determine how the mathematical representation abilities of STKIP Melawi students. The research method was descriptive qualitative with a survey research form. The research subjects were 25 people from the Mathematics Education student population, namely 51 people. Subjects were selected by simple random sampling without knowing the initial mathematical ability of each student. Data collection techniques using test and interview techniques. The research instrument used was a representation ability test question sheet and interview guidelines. The data analysis used was data reduction, data presentation, and conclusion. Students are interviewed after answering the questions given. Presentation of the results of data processing in the form of descriptions which then draw conclusions. The results showed that students who answered questions according to the indicators using visual representations (pictures) to solve math problems were categorized as high and students who answered questions according to the indicators translated from verbal representations (written) into visual representations (pictures) of mathematics with writing categorized as low.
\end{abstract}

Keywords: ability; mathematical representation; plane figure. 
Edukasi: Jurnal Pendidikan, Volume 19 Nomor 1 Tahun 2021

Analisis Kemampuan Representasi Matematis Mahasiswa

Yumi Sarassanti

Halaman 60-74

\section{PENDAHULUAN}

Salah satu ciri matematika yakni memiliki benda yang abstrak. Sifat abstrak membuat banyak mahasiswa mengalami kesulitan dalam mempelajari matematika (Sari et al., 2018; Novitasari, 2016). Terkadang, mahasiswa belajar matematika tanpa mengetahui tujuan dari mempelajari ilmu matematika dan apa manfaat ilmu yang dipelajari bagi kehidupan, sehingga mahasiswa hanya belajar berhitung saja untuk mendapatkan nilai. Hal tersebut juga terjadi pada mahasiswa STKIP Melawi. Hasil kuis dan soal latihan selama perkuliahan menunjukkan bahwa masih terdapat kesulitan dalam mempelajari bentuk geometri yang merupakan bagian dari matematika. Misalnya pada saat menyelesaikan soal mengenai keliling dan luas bangun datar, mahasiswa kesulitan membedakan tinggi, alas, sisi, panjang, lebar, dan diagonal.

Mahasiswa STKIP Melawi juga mengalami kesulitan membuat sketsa gambar serta menyelesaikan persoalan yang ada pada gambar. Hal tersebut karena mahasiswa tidak memahami langkah-langkah dalam menyelesaikan soal-soal yang diberikan. Matematika memiliki standar proses dalam pembelajaran, seperti pemecahan masalah, penalaran, berkomunikasi, menghubungkan, dan merepresentasikan keterampilan (NCTM, 2000). Berdasarkan pendapat NCTM tersebut, kemampuan mahasiswa dalam membuat representasi merupakan bagian dari standar proses pembelajaran matematika, sehingga mahasiswa harus memiliki kemampuan representasi matematis.

Uraian mengenai masalah di STKIP Melawi serta pentingnya representasi matematis memotivasi peneliti untuk mengkaji lebih dalam berkaitan kemampuan representasi matematis mahasiswa STKIP Melawi berhubungan dengan bangun datar. Representasi merupakan ungkapan dari ide atau gagasan mahasiswa untuk mengubah ide abstrak menjadi ide yang nyata digunakan untuk mencari solusi, misalnya permasalahan bisa direpresentasikan dengan objek, foto, kata-kata, atau simbol matematika (Fitri et al., 2017). Berdasarkan laporan hasil Trends in International Mathematics and Science Study diketahui bahwa siswa SMP di Indonesia memiliki kemampuan yang rendah dalam mengungkapkan ide atau konsep matematika, seperti materi pembagian bilangan, aljabar, geometri, 
representasi data, analisis, dan peluang (Hadi \& Novaliyosi, 2019). Representasi merupakan penjelasan dari hasil pemikiran mahasiswa mengenai suatu permasalahan dan merupakan solusi dari permasalahan (Sabirin, 2014). Bentuk penafsiran atau pengungkapan pemikiran mahasiswa dapat berupa kata-kata, tabel, tulisan, gambar, benda konkret, grafik, simbol matematika, dan lainnya.

Representasi matematis mengacu pada deskripsi, terjemahan, pengungkapan kembali, simbolisasi, dan bahkan permodelan konsep matematika dan hubungan yang disajikan dalam berbagai bentuk, baik struktur atau situasi masalah tertentu yang dapat memberikan pemahaman atau menemukan solusi atas masalah yang dihadapi (Rangkuti, 2013). Untuk memahami konsep matematika yang dibutuhkan seorang mahasiswa bukan pengalaman sebelumnya, akan tetapi bagaimana mahasiswa tersebut membentuk kembali pengetahuan yang disimpan dalam ingatannya sehingga dapat digunakan ketika diperlukan. Proses tersebut yang dikatakan representasi internal. Sehingga, mahasiswa yang melakukan proses internal dalam belajar matematika akan berpikir bahwa yang sedang dipelajarinya akan dimaknai secara jelas dengan menghubungkan permasalahan dengan ilmu yang telah dimilikinya, serta merumuskan strategi pemecahannya. Adapun representasi eksternal merupakan hasil realisasi dari apa yang dikerjakan mahasiswa, guru, ahli matematik secara representasi internal. Hasil representasi diungkapkan secara lisan atau tulisan dalam bentuk kata-kata, notasi matematika, gambar, atau melalui objek fisik berupa alat peraga.

Representasi adalah suatu bentuk alternatif dari permasalahan yang dicari solusinya (Mustangin, 2015). Situasi masalah dapat diwakili oleh objek atau simbol matematika. Representasi tidak hanya produk, tetapi juga proses (Wiryanto, 2015). Pemahaman mengenai objek matematika berkaitan dengan keberadaan representasi internal dalam jaringan representasi dan keterkaitannya, sehingga dapat membentuk representasi eksternal yang bermakna dan dapat dikomunikasikan. Ragam representasi yang sering digunakan dalam merepresentasikan matematika antara lain: (1) Penyajian visual seperti tabel, grafik, dan gambar; (2) Pernyataan atau simbol matematika; dan (3) Teks tertulis yang tulis dalam bahasa sendiri baik formal maupun informal (Mustangin, 2015). 
Edukasi: Jurnal Pendidikan, Volume 19 Nomor 1 Tahun 2021

Analisis Kemampuan Representasi Matematis Mahasiswa

Yumi Sarassanti

Halaman 60-74

Indikator kemampuan representasi matematis menurut NCTM, yaitu: (1) Permodelan fisik dan interpretasi masalah matematika menggunakan representasi; (2) Membuat representasi dan digunakan mengatur serta merekam, dan bertukar ide matematika; dan (3) Memilah, mengaplikasikan, dan menerjemahkan simbol matematika untuk menyelesaikan permasalahan matematika (Sanjaya et al., 2018). Kemampuan representasi harus dimiliki oleh mahasiswa untuk dapat menyelesaikan masalah dengan menampilkannya ke berbagai model penyelesaian baik secara visual, verbal, tabel, benda konkret maupun simbol matematika sebagai hasil proses menuangkan pemikiran untuk menyelesaikan masalah. Berdasarkan permasalahan yang telah diuraikan, maka penelitian bertujuan untuk mengetahui bagaimana kemampuan representasi matematis mahasiswa STKIP Melawi pada materi Bangun Datar.

\section{METODE}

Penelitian bersifat kualitatif deskriptif dengan bentuk penelitian survei. Penelitian dilakukan pada sampel yang diambil dari populasi mahasiswa Pendidikan Matematika di STKIP Melawi. Subjek penelitian yang digunakan berjumlah 25 orang dari populasi mahasiswa Pendidikan Matematika yaitu 51 orang. Subjek penelitian dipilih secara simple random sampling tanpa diketahui kemampuan awal matematika setiap mahasiswa. Peneliti menganalisis hasil jawaban mahasiswa mengenai soal bangun datar. Pengumpulan data menggunakan teknik tes dan wawancara. Alat pengumpulan data menggunakan soal tes dan pedoman wawancara.

Terdapat 3 soal indikator menggunakan representasi visual (gambar) untuk menyelesaikan masalah matematika dan 2 soal indikator melakukan translasi dari representasi verbal (tulisan) ke dalam representasi visual (gambar) matematika dengan tulisan dan menyelesaikan masalah dalam representasi. Soal tes berisi 5 soal yang terdiri dari 4 jenis soal bangun datar, yakni belah ketupat, jajar genjang, layang-layang, dan trapesium yang penyelesaiannya dikerjakan oleh subjek penelitian. Dengan demikian, subjek penelitian leluasa menuntaskan permasalahan berdasarkan pemikirannya sendiri. Penilaian setiap soal 
menggunakan skor. Penggolongan skor untuk setiap soal dibuat berdasarkan tingkat kesulitan soal bangun datar. Apabila skor yang diperoleh semakin besar, maka kesulitan dalam merepresentasikan soal tersebut semakin sulit seperti telihat pada pedoman penskoran soal nomor 1,3, dan 4, sedangkan semakin kecil skor, seperti pada soal nomor 2 dan 5, karena soal tersebut penyelesaiannya dalam merepresentasikan tidak rumit dan mudah. Pedoman penskoran terlihat pada Tabel 1.

Tabel 1 Pedoman Penskoran Tes Kemampuan Representasi Matematis

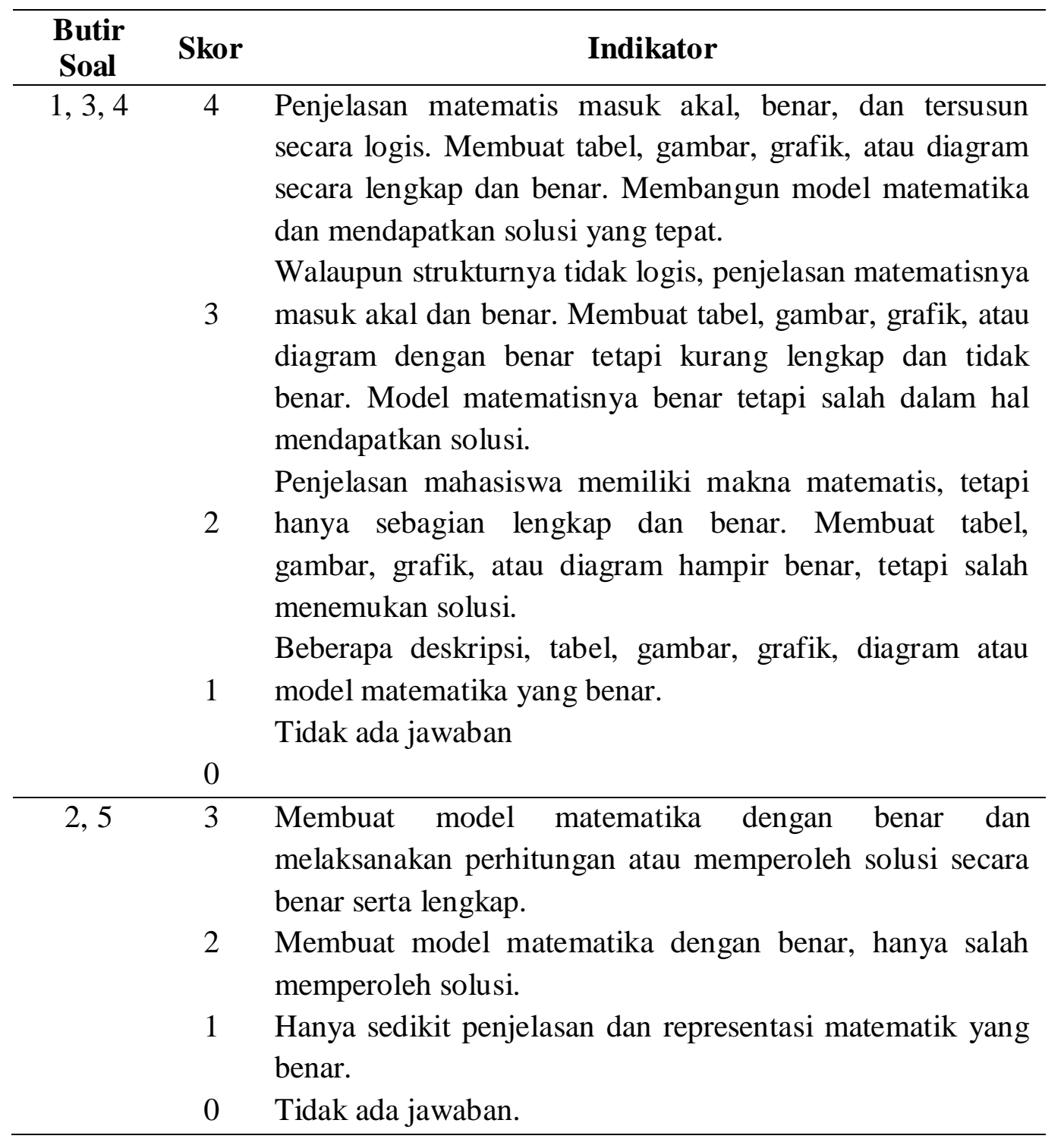

Wawancara dilaksanakan dengan 2 orang mahasiswa kriteria rendah, 2 orang mahasiswa kriteria sedang, dan 2 orang mahasiswa kriteria tinggi yang 
Edukasi: Jurnal Pendidikan, Volume 19 Nomor 1 Tahun 2021

Analisis Kemampuan Representasi Matematis Mahasiswa

Yumi Sarassanti

Halaman 60-74

diambil secara random dari tiap-tiap soal tes kemampuan representasi matematis. Masing-masing mahasiswa diwawancarai pada soal-soal yang tidak dijawab dengan benar serta apa kesulitan dalam menanggapi soal tersebut. Teknik pengolahan data menggunakan statistik deskriptif. Analisis kemampuan representasi matematis menggunakan perhitungan persentase seperti rumus (1) (Qomusuddin, 2019).

$$
\text { Persentase } \%=\frac{\text { Jumlah skor yg di peroleh }}{\text { Skor maksimal }} \times 100 \%
$$

Berdasarkan hasil persentase kemampuan representasi mahasiswa, maka pengkategorian kemampuan representasi mahasiswa terlihat pada Tabel 2.

Tabel 2 Kriteria Kemampuan Representasi Matematis

\begin{tabular}{cc}
\hline Kategori & Persentase \\
\hline Rendah & $0 \%-50 \%$ \\
Sedang & $51 \%-80 \%$ \\
Tinggi & $81 \%-100 \%$ \\
\hline
\end{tabular}

\section{HASIL DAN PEMBAHASAN}

Hasil penelitian menunjukkan kategori-kategori berdasarkan pada jawaban mahasiswa.

Tabel 3 Frekuensi Mahasiswa dalam Menjawab Soal Bangun Datar

\begin{tabular}{lccc}
\hline \multicolumn{1}{c}{ Indikator Soal } & Kriteria & Persentase & Frekuensi \\
\hline Mahasiswa dapat & Rendah & $0 \%-50 \%$ & 0 mahasiswa \\
menghitung keliling dan luas & Sedang & $51 \%-80 \%$ & 12 mahasiswa \\
$\begin{array}{l}\text { bangun datar melalui sketsa } \\
\text { gambar }\end{array}$ & Tinggi & $81 \%-100 \%$ & 13 mahasiswa \\
\hline $\begin{array}{l}\text { Mahasiswa dapat membuat } \\
\text { sketsa suatu model }\end{array}$ & Rendah & $0 \%-50 \%$ & 11 mahasiswa \\
$\begin{array}{l}\text { matematika dan } \\
\text { mendapatkan solusinya }\end{array}$ & Sedang & $51 \%-80 \%$ & 12 mahasiswa \\
\hline
\end{tabular}

Berdasarkan Tabel 3, disimpulkan bahwa mahasiswa yang mampu menyelesaikan masalah dengan indikator menggunakan representasi visual (gambar) untuk menyelesaikan soal matematika termasuk kriteria tinggi. 
Tabel 4 Hasil Analisis Jawaban Mahasiswa

\begin{tabular}{|c|c|c|c|c|c|c|c|c|c|}
\hline \multirow{4}{*}{ Nama } & \multicolumn{5}{|c|}{ Indikator Representasi 1} & \multicolumn{4}{|c|}{ Indikator Representasi 2} \\
\hline & \multicolumn{9}{|c|}{ Soal Bangun Datar } \\
\hline & $\begin{array}{c}\text { Soal } \\
1\end{array}$ & $\begin{array}{c}\text { Soal } \\
\mathbf{3}\end{array}$ & $\begin{array}{c}\text { Soal } \\
4\end{array}$ & $\%$ & $\mathbf{K r}$ & $\begin{array}{c}\text { Soal } \\
2\end{array}$ & $\begin{array}{c}\text { Soal } \\
5\end{array}$ & $\%$ & $\mathbf{K r}$ \\
\hline & \multicolumn{5}{|c|}{ Skor } & \multicolumn{4}{|c|}{ Skor } \\
\hline Subjek F1 & 4 & 3 & 4 & 91 & $\mathrm{~T}$ & 1 & 2 & 50 & $\mathrm{R}$ \\
\hline Subjek F2 & 3 & 3 & 3 & 75 & $\mathrm{~S}$ & 2 & 2 & 67 & S \\
\hline Subjek F3 & 4 & 3 & 3 & 83 & $\mathrm{~T}$ & 2 & 2 & 67 & S \\
\hline Subjek F4 & 3 & 3 & 3 & 75 & $\mathrm{~S}$ & 1 & 2 & 50 & $\mathrm{R}$ \\
\hline Subjek F5 & 2 & 4 & 3 & 75 & $\mathrm{~S}$ & 2 & 2 & 67 & $\mathrm{~S}$ \\
\hline Subjek F6 & 3 & 4 & 4 & 92 & $\mathrm{~T}$ & 2 & 2 & 67 & $\mathrm{~S}$ \\
\hline Subjek F7 & 3 & 3 & 3 & 75 & $\mathrm{~S}$ & 2 & 2 & 67 & $\mathrm{~S}$ \\
\hline Subjek F8 & 3 & 4 & 3 & 83 & $\mathrm{~T}$ & 2 & 2 & 67 & $\mathrm{~S}$ \\
\hline Subjek F9 & 4 & 4 & 4 & 100 & $\mathrm{~T}$ & 1 & 2 & 50 & $\mathrm{R}$ \\
\hline Subjek F10 & 3 & 3 & 3 & 75 & $\mathrm{~S}$ & 2 & 2 & 67 & $\mathrm{~S}$ \\
\hline Subjek F11 & 2 & 4 & 3 & 75 & $\mathrm{~S}$ & 1 & 2 & 50 & $\mathrm{R}$ \\
\hline Subjek F12 & 3 & 3 & 4 & 83 & $\mathrm{~T}$ & 2 & 1 & 50 & $\mathrm{R}$ \\
\hline Subjek F13 & 3 & 3 & 3 & 75 & $\mathrm{~S}$ & 2 & 2 & 67 & $\mathrm{~S}$ \\
\hline Subjek F14 & 4 & 3 & 4 & 92 & $\mathrm{~T}$ & 2 & 1 & 50 & $\mathrm{R}$ \\
\hline Subjek F15 & 4 & 3 & 3 & 83 & $\mathrm{~T}$ & 2 & 2 & 67 & $\mathrm{~S}$ \\
\hline Subjek F16 & 4 & 3 & 3 & 83 & $\mathrm{~T}$ & 1 & 2 & 50 & $\mathrm{R}$ \\
\hline Subjek F17 & 3 & 3 & 3 & 75 & $\mathrm{~S}$ & 2 & 2 & 67 & $\mathrm{~S}$ \\
\hline Subjek F18 & 3 & 4 & 3 & 83 & $\mathrm{~T}$ & 2 & 1 & 50 & $\mathrm{R}$ \\
\hline Subjek F19 & 3 & 4 & 2 & 75 & $\mathrm{~S}$ & 1 & 2 & 50 & $\mathrm{R}$ \\
\hline Subjek F20 & 3 & 3 & 3 & 75 & $\mathrm{~S}$ & 3 & 2 & 83 & $\mathrm{~T}$ \\
\hline Subjek F21 & 3 & 3 & 3 & 75 & $\mathrm{~S}$ & 2 & 2 & 67 & $\mathrm{~S}$ \\
\hline Subjek F22 & 4 & 4 & 3 & 92 & $\mathrm{~T}$ & 1 & 2 & 50 & $\mathrm{R}$ \\
\hline Subjek F23 & 3 & 3 & 3 & 75 & $\mathrm{~S}$ & 2 & 3 & 83 & $\mathrm{~T}$ \\
\hline Subjek F24 & 3 & 4 & 4 & 92 & $\mathrm{~T}$ & 1 & 2 & 50 & $\mathrm{R}$ \\
\hline Subjek F25 & 4 & 3 & 3 & 83 & $\mathrm{~T}$ & 2 & 2 & 67 & $\mathrm{~S}$ \\
\hline
\end{tabular}

Keterangan: Soal nomor 1, 3, dan 4 dengan skor maksimal 4, termasuk indikator representasi 1, yakni memanfaatkan representasi visual (gambar) untuk menyelesaikan masalah matematika; soal nomor 2 dan 5 dengan skor maksimal 3 dengan indikator representasi 2, yakni melakukan translasi dari representasi verbal (tulisan) ke dalam representasi visual (gambar) matematika dengan tulisan dan menyelesaikan masalah dalam representasi; $\mathrm{Kr}$ adalah Kriteria; $\mathrm{T}$ adalah Tinggi; $\mathrm{S}$ adalah Sedang; R adalah Rendah.

Mahasiswa yang menyelesaikan soal indikator pertama memahami langkahlangkah penentuan keliling dan luas bangun datar melalui sketsa gambar. 
Edukasi: Jurnal Pendidikan, Volume 19 Nomor 1 Tahun 2021

Analisis Kemampuan Representasi Matematis Mahasiswa

Yumi Sarassanti

Halaman 60-74

Sedangkan mahasiswa dengan kriteria sedang mampu memecahkan masalah indeks dengan menerjemahkan dari representasi verbal (tertulis) ke representasi visual (gambar) matematika melalui tulisan dan pemecahan masalah dalam representasi. Sehingga ada mahasiswa yang dapat membuat sketsa model matematika dan menemukan solusinya dan ada pula mahasiswa yang tidak dapat membuat sketsa dengan benar tetapi dapat menyelesaikannya dengan mengikuti langkah-langkah yang sesuai. Dalam pembelajaran matematika, representasi merupakan landasan bagaimana seorang mahasiswa bisa memahami serta menggunakan ide matematika. Data uji awal dipergunakan sebagai topik utama melalui pengambilan sampel bertingkat, yang mengambil dua topik dari setiap kriteria (Amaliyah \& Mahmud, 2018).

Berikut salah satu langkah penyelesaian soal oleh subjek F20 memakai representasi visual (gambar) untuk menyelesaikan permasalahan matematika.

Jika $\mathrm{AB}=4 \mathrm{~cm}, \mathrm{BC}=5 \mathrm{~cm}, \mathrm{CD}=7$, dan $\mathrm{AD}=4 \mathrm{~cm}$. Tentukan keliling dan luas trapesium!

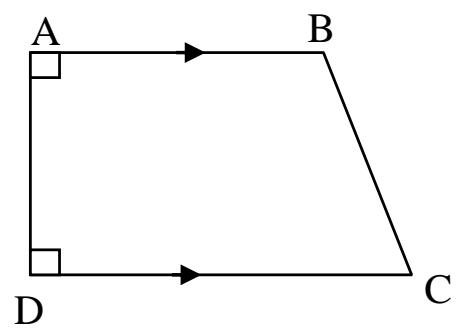

\section{Gambar 1 Bangun Datar Trapesium}

Penyelesaian:

Diketahui: $\mathrm{AB}=4 \mathrm{~cm}, \mathrm{BC}=5 \mathrm{~cm}, \mathrm{CD}=7$, dan $\mathrm{AD}=4 \mathrm{~cm}$.

Ditanya: Keliling trapesium?

Jawab:

$$
\text { Keliling }(\mathrm{K}) \quad \begin{array}{ll} 
& =\mathrm{AB}+\mathrm{BC}+\mathrm{CD}+\mathrm{AD} \\
& =4 \mathrm{~cm}+5 \mathrm{~cm}+7 \mathrm{~cm}+4 \mathrm{~cm} \\
& =20 \mathrm{~cm}
\end{array}
$$

Jadi, Keliling $(\mathrm{K}) \quad=20 \mathrm{~cm}$. 
Berdasarkan langkah penyelesaian soal mengenai bangun datar trapesium dapat ditarik kesimpulan bahwa subjek menyelesaikan soal dengan langkah yang cukup tepat, namun ada solusi yang kurang untuk diselesaikan yakni tidak menentukan luas dari bangun datar trapesium yang ditanyakan dalam soal. Kemampuan matematis siswa kelas VII ditinjau dari Teori Van Hiele, siswa hanya mampu pada level 2 (deduksi informal) karena siswa mengalami kekurangan kosakata dalam mengungkapkan ide-ide yang dimiliki untuk menyelesaikan soal yang diberikan (Herlambang, 2013). Beberapa penyebab siswa mengalami kesalahan yakni tidak bisa menyusun makna kata yang dipikirkan ke dalam bentuk matematika, kurang teliti, serta kurang memahami soal (Ardiana et al., 2019).

Subjek F20 hanya mencari nilai keliling dengan cara merepresentasikan bentuk visual dari gambar trapesium ke dalam simbol matematika. Dari uraian pembahasan mengenai langkah-langkah pemecahan masalah terdiri dari dua cara, yakni merepresentasikan masalah serta penyelesaian masalah. Apabila tidak ada permasalahan yang berhasil berarti penyelesaian masalah yang berhasil tidak mungkin dilakukan. Penyajian permasalahan yang tepat merupakan dasar untuk memahami dan merumuskan rencana untuk pemecahan masalah. Mahasiswa yang kesulitan menampilkan masalah matematika, maka akan kesulitan dalam menyelesaikannya. Treffers menyatakan bahwa permasalahan realistik yang digunakan adalah sebagai titik awal pembelajaran matematika (Wijaya, 2012). Penyelesaian soal oleh subjek F20 berkaitan indikator melakukan translasi dari representasi verbal (tulisan) ke dalam representasi visual (gambar) matematika dengan tulisan dan menyelesaikan masalah dalam representasi.

Jika diketahui panjang PS $=13 \mathrm{~cm}, \mathrm{SR}=20 \mathrm{~cm}$, dan Panjang $\mathrm{SQ}=24 \mathrm{~cm}$, dimana PR merupakan sumbu simetri dan $\mathrm{O}$ merupakan titik potong kedua diagonal. Gambarlah Layang-layang PQRS tersebut dan tentukan luasnya?

Penyelesaian:

Diketahui: $\mathrm{SQ}=24 \mathrm{~cm}$, Maka $\mathrm{QO}=\mathrm{OS}=12 \mathrm{~cm}, \mathrm{PS}=13 \mathrm{~cm}$, dan $\mathrm{SR}=20 \mathrm{~cm}$. 
Edukasi: Jurnal Pendidikan, Volume 19 Nomor 1 Tahun 2021

Analisis Kemampuan Representasi Matematis Mahasiswa

Yumi Sarassanti

Halaman 60-74

Ditanya: Luas layang-layang?

Jawab:

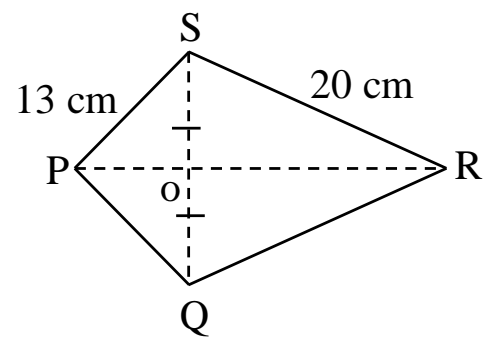

\section{Gambar 2 Bangun Datar Layang-layang}

$\mathrm{PR}=\mathrm{PO}+\mathrm{OR}$

$$
\begin{aligned}
& =\sqrt{13^{2}-12^{2}}+\sqrt{20^{2}-12^{2}} \\
& =\sqrt{25}+\sqrt{256}=21 \mathrm{~cm}
\end{aligned}
$$

Jadi, luas layang-layang sebesar

$$
\mathrm{L}=\frac{1}{2} \mathrm{QS} . \mathrm{PR}=\frac{1}{2} \cdot 24 \mathrm{~cm} \cdot 21 \mathrm{~cm}=252 \mathrm{~cm}^{2}
$$

Berdasarkan hasil penyelesaian subjek F20 dapat ditarik kesimpulan bahwa subjek dapat menyelesaikan soal dengan baik yang termasuk kriteria tinggi untuk merepresentasikan soal ke bentuk visual. Subjek sudah menyusun secara logis langkah-langkah penyelesaian. Subjek sudah membuat gambar dengan benar, namun kurang lengkap pada langkah penyelesaian yakni mendapatkan nilai QS sehingga menjadi $24 \mathrm{~cm}$.

Hasil analisis data menunjukkan bahwa kemampuan melakukan translasi dari representasi verbal (tulisan) ke dalam representasi visual (gambar) matematika dengan tulisan dan menyelesaikan masalah mahasiswa Pendidikan Matematika STKIP Melawi masih rendah dan perlu diberikan treatment yang dapat meningkatkan kemampuan representasi matematis khususnya melakukan translasi dari representasi verbal (tulisan) ke dalam representasi visual (gambar) matematika dengan tulisan dan menyelesaikan masalah dalam representasi tersebut. Berdasarkan wawancara dengan beberapa responden, subjek kesulitan dalam melakukan translasi representasi verbal ke dalam representasi visual disebabkan tidak bisa mengukur panjang dari sisi yang sejajar dan sudut yang 
sama sehingga gambar yang dibuat tidak sesuai dengan gambar yang seharusnya. Penyebab lainnya yaitu dalam perhitungan rumus ataupun hasil dari perhitungan masih terdapat kesalahan, sehingga apabila diubah ke dalam representasi visual (gambar) tidak sesuai dengan ukuran yang diinginkan.

Contoh berikut menunjukkan soal matematika yang terkait dengan representasi matematika "Jika panjang sisi dua kali panjang aslinya, apa yang terjadi dengan luas persegi panjang?" Masalah persegi panjang menarik karena menantang mahasiswa untuk memikirkan tantangan dalam memanfaatkan penjelasan yang tersedia dan menghubungkannya dengan pengetahuan sebelumnya. Ada banyak cara untuk memecahkan masalah luas persegi panjang.

Masalah luas persegi panjang juga dapat diselesaikan dengan lebih dari satu cara. Contoh masalah yang mungkin diselesaikan mahasiswa adalah dengan menggunakan notasi simbolis untuk menyelesaikan masalah secara langsung, seperti yang ditunjukkan pada pernyataan bahwa panjang persegi panjang asli adalah a dan lebarnya adalah $b$, maka luasnya adalah

$$
L=a \times b=a b
$$

Jika panjang sisinya dua kali panjang aslinya, maka panjangnya adalah 2a dan lebarnya $2 b$, maka luasnya adalah

$$
L=2 a \times 2 b=4 a b
$$

Berdasarkan pada jawaban tersebut, maka disimpulkan bahwa luas persegi panjang baru akan menjadi 4 kali luas persegi panjang aslinya. Selain metode tersebut, beberapa mahasiswa dengan cepat berpikir dan segera menjawab bahwa luasnya dua kali luas persegi panjang aslinya. Dosen harus berusaha memberikan pemahaman yang mudah dipahami agar pemikiran mahasiswa lebih kritis dan juga kreatif, misalnya meminta mahasiswa menjawab atau memanfaatkan metode lain untuk berpikir ulang. Sedikit mahasiswa yang memilih menggunakan notasi simbolis saat berkomunikasi atau menyampaikan ide matematika (Rima, 2014). Mahasiswa yang berfokus pada penggunaan representasi aljabar (simbolis) cenderung menjadi mahasiswa yang terampil. Pernyataan tersebut sejalan dengan fakta bahwa dalam penelitian yang dilakukan sebagian subjek lebih cenderung merepresentasikan bentuk representasi simbolik memiliki kemampuan tinggi. 
Edukasi: Jurnal Pendidikan, Volume 19 Nomor 1 Tahun 2021

Analisis Kemampuan Representasi Matematis Mahasiswa

Yumi Sarassanti

Halaman 60-74

Mahasiswa tingkat bawah mungkin tidak dapat memahami materi tingkat yang lebih tinggi. Jika tingkat berpikir mahasiswa berada pada tahap pengantar, mahasiswa hanya dapat mengekspresikan gambar geometris saat menyelesaikan masalah segi empat, dan mahasiswa tidak dapat menyelesaikan masalah berikutnya. Mahasiswa yang tingkat pemikirannya sudah dalam tahap deduktif tidak hanya dapat mengekspresikan gambar, tetapi juga mengekspresikan lebih banyak benda. Kemampuan representasi matematika mahasiswa tergolong baik dalam pembelajaran berbasis Teori Van Hiele mengenai materi persegi panjang (Armadan et al., 2017). Mahasiswa akan memecahkan masalah segi empat, seperti simbol matematika untuk menyelesaikan jawaban atas masalah tersebut (Armadan et al., 2017). Proses pemecahan masalah yang sukses bergantung pada keterampilan representasi masalah, seperti membangun dan menggunakan representasi matematis dalam kata, grafik, tabel, persamaan, serta memecahkan dan memanipulasi simbol (Fuad, 2016).

Berdasarkan hasil analisis data dan hasil penelitian terdahulu, disimpulkan bahwa kemampuan representasi mahasiswa secara visual tidak hanya melalui gambar saja, namun bisa berupa tabel, grafik atau penyelesaian lain tergantung dari kemampuan representasi masing-masing mahasiswa. Semakin baik kemampuan representasi mahasiswa, maka semakin banyak yang dapat direpresentasikan dalam menyelesaikan suatu permasalahan. Mahasiswa berkomunikasi dengan kelompok dalam proses berdiskusi dengan kelompok, mengunjungi dan menerima mahasiswa dari kelompok lain, presentasi ke depan kelas, tanya-jawab, dan menguasai konsep dalam proses pembelajaran (Kadiriandi \& Ruyadi, 2017; Suryanti et al., 2017; Nurhasanah, 2012).

Berdiskusi, mengunjungi, dan menerima mahasiswa dari kelompok lain, serta presentasi di depan kelas akan membentuk kemampuan representasi verbal mahasiswa. Dalam pembelajaran diskusi, mahasiswa berkomunikasi dan tanya jawab selama perkuliahan. Kemampuan verbal mahasiswa apabila semakin tinggi intensitas komunikasi mahasiswa, maka semakin tinggi pula kemampuannya dalam merepresentasikan masalah matematika yang dihadapi (Khairuntika et al., 2014). Berdasarkan pembahasan tersebut, maka disimpulkan bahwa kegiatan 
mahasiswa di kelas akan menunjang kemampuan representasi mahasiswa dalam menyelesaikan suatu permasalahan. Semakin sering mahasiswa melakukan komunikasi, maka akan menunjang kemampuan mahasiswa dalam melakukan representasi verbal menjadi lebih baik untuk direpresentasikan ke visual.

\section{SIMPULAN}

Berdasarkan hasil analisis data, disimpulkan bahwa mahasiswa Pendidikan Matematika di STKIP Melawi yang menjawab soal sesuai indikator menggunakan representasi visual (gambar) untuk menyelesaikan masalah matematika dikategorikan tinggi dan mahasiswa yang menjawab soal sesuai dengan indikator melakukan translasi dari representasi verbal (tulisan) ke dalam representasi visual (gambar) matematika dengan tulisan dikategorikan rendah.

\section{DAFTAR PUSTAKA}

Amaliyah, A. R. R., \& Mahmud, N. (2018). Analisis kemampuan representasi matematis dalam pemecahan masalah geometri serta faktor-faktor yang mempengaruhinya. JRPM (Jurnal Review Pembelajaran Matematika), 3(2), 146-160. https://doi.org/10.15642/jrpm.2018.3.2.146-160.

Ardiana, N. A., Arigiyati, T. A., \& Nasroni, N. (2019). Analisis kemampuan pemecahan masalah matematika siswa kelas X SMK Muhammadiyah 1 Imogiri. Prosiding Sendika: Bidang Pendidikan Matematika.

Armadan, Somakim, \& Indaryanti. (2017). Kemampuan representasi matematis mahasiswa pada pembelajaran berbasis Teori Van Hiele di materi Segi empat kelas VII SMP Negeri 1 Indralaya Utara. Jurnal Elemen, 3(1), 49-57.

Fitri, N., Munzir, S., \& Duskri, M. (2017). Meningkatkan kemampuan representasi matematis melalui penerapan model problem based learning. Jurnal Didaktik Matematika, 4(1), 59-67. https://doi.org/10.24815/ jdm.v4i1.6902.

Fuad, M. N. (2016). Representasi matematis siswa SMA dalam memecahkan masalah persamaan kuadrat ditinjau dari perbedaan gender. Kreano Jurnal 
Edukasi: Jurnal Pendidikan, Volume 19 Nomor 1 Tahun 2021

Analisis Kemampuan Representasi Matematis Mahasiswa

Yumi Sarassanti

Halaman 60-74

Matematika Kreatif-Inovatif, 7(2), 145-152. https://doi.org/10.15294/ kreano.v7i2.5854.

Hadi, S., \& Novaliyosi, N. (2019). TIMSS Indonesia (Trends in International Mathematics and Science Study). Prosiding Seminar Nasional Implementasi Riset Kuantatif, R\&D, dan Mix Method pada Era Revolusi Industri 4.0.

Herlambang, H. (2013). Analisis kemampuan pemecahan masalah matematika Siswa kelas VII-A SMP Negeri 1 Kepahiang ditinjau dari Teori Van Hiele. Disertasi: Universitas Negeri Bengkulu. Tidak dipublikasikan.

Kadiriandi, R., \& Ruyadi, Y. (2017). Pengaruh penerapan model pembelajaran model Two Stay Two Stray (TSTS) terhadap peningkatan keaktifan dan hasil belajar sosiologi di SMA Pasundan 3 Bandung. Sosietas Jurnal Pendidikan Sosiologi, 7(2), 429-433. https://doi.org/10.17509/ sosietas.v7i2.10362.

Khairuntika, Yunarti, T., \& Noer, S. H. (2014). Meningkatkan Kemampuan Representasi Matematis Mahasiswa Melalui Pembelajaran Kooperatif Tipe TSTS. Jurnal Pendidikan Matematika, 2(6), 1-9.

Mustangin. (2015). Representasi konsep dan peranannya dalam pembelajaran matematika di sekolah. Jurnal Pendidikan Matematika, 1(1), 15-21.

NCTM. (2000). Principles and standards for school mathematic. Reston, Virginia: NCTM lnc.

Novitasari, D. (2016). Pengaruh penggunaan multimedia interaktif terhadap kemampuan pemahaman konsep matematis mahasiswa. Fibonacci: Jurnal Pendidikan Matematika dan Matematika, 2(2), 8-18. https://doi.org/ 10.24853/fbc.2.2.8-18.

Nurhasanah, F. (2012). Membangun keaktifan mahasiswa pada proses pembelajaran mata kuliah perencanaan dan pengembangan program pembelajaran matematika melalui pendekatan konstrutivisme dalam kegiatan lesson study. Infinity Journal, 1(1), 62-78. http://dx.doi.org/ 10.22460/infinity.v1i1.p62-78.

Qomusuddin, I. F. (2019). Statistik pendidikan (Lengkap dengan aplikasi IMB SPSS Statistic 20.0). Yogyakarta: Deepublish. 
Rangkuti, A. N. (2013). Representasi matematis. Logaritma: Jurnal Ilmu-ilmu Pendidikan dan Sains, 1(02). https://doi.org/10.24952/logaritma.v1i02.222.

Rima, A. C. (2014). Representasi matematis mahasiswa kelas VII SMP N 9 Yogyakarta dalam membangun konsep sistem persamaan linear dua variabel. Tesis: Universitas Sebelas Maret. Tidak dipublikasikan.

Sabirin, M. (2014). Representasi dalam pembelajaran matematika. Jurnal Pendidikan Matematika, 1(2), 33-42. http://dx.doi.org/10.18592/ jpm.v1i2.49.

Sanjaya, I. I., Maharani, H. R., \& Basir, M. A. (2018). Kemampuan representasi matematis mahasiswa pada materi Lingkaran berdasar gaya belajar Honey Mumfrod. Jurnal Penelitian Didaktik Matematika, 2(2),72-87. http://dx.doi.org/10.30659/kontinu.2.1.72-87.

Sari, F., Darma, Y., \& Dafrita, I. (2018). Pengembangan media pembelajaran powerpoint integrasi geogebra untuk meningkatkan kemampuan representasi matematis dalam materi Refleksi. Edukasi: Jurnal Pendidikan, 16(2), 281-289. http://dx.doi.org/10.31571/edukasi.v16i2.1026.

Suryanti, S., Khikmiyah, F., Zawawi, I., \& Fauziyah, S. (2017). Peningkatan penguasaan konsep matriks melalui model pembelajaran kooperatif Tipe Two Stay Two Stray (TSTS). Didaktika: Jurnal Pemikiran Pendidikan, 21(1), 14-27. http://journal.umg.ac.id/index.php/didaktika/article/view/96.

Wijaya, A (2012). Pendidikan matematika realistik: Suatu alternatif pendekatan pembelajaran matematika. Yogyakarta: Graha Ilmu.

Wiryanto. (2015). Abstraksi Mahasiswa Sekolah Dasar dalam Representasi Konsep Pecahan melalui Tahap Perkembangan Kognitif Bruner Berdasarkan Perbedaan Gender. Disertasi: Universitas Negeri Surabaya. Tidak dipublikasikan. 